\title{
PENGUATAN PEMBELAJARAN SEJARAH DI ERA DISRUPSI (REKONSTRUKSI PEMBELAJARAN SEJARAH REGRESI)
}

\author{
Wisnu \\ Email: wisnu@unesa.ac.id \\ Dosen Pendidikan Sejarah FISH Unesa Surabaya
}

\begin{abstract}
Abstrak
Pembelajaran sejarah memiliki peran penting dalam mengembangkan kemampuan siswa untuk berpikir kritis dan membangunan karakter. Namun, berbagai fakta menunjukkan bahwa siswa benar-benar menunjukkan sikap yang bertentangan dengan peran historis yang dimaksud. Mereka cenderung meremehkan peran pembelajaran sejarah. Mereka cenderung bosan dan mengesampingkan peran pelajaran sejarah. Adanya anggapan tersebut merupakan tantangan serius yang harus dihadapi oleh berbagai pihak, terutama guru di sekolah sebagai ujung tombak pendidikan sejarah. Salah satu upaya untuk mengubah asumsi siswa adalah mencari terobosan dalam studi sejarah di era disrupsi. Fenomena disrupsi menjadi penting untuk melihat masa lampau sebagai langkah menata masa kini dan bekal menata masa depan. Pembelajaran sejarah menjadi landasan dasar membangun karakter di era disrupsi. Alternatif yang bisa dilakukan, yaitu dengan teknik flash back fenomena sejarah hari ini menuju ke pemahaman masa lalu. Jika pembelajaran sejarah secara umum bertolak dari materi "masa lalu" ke arah "masa kini", maka mungkinkah pembelajaran sejarah diajarkan (dipelajari) dengan beralih dari konteks "masa kini" ke materi "masa lalu"? Jika demikian, langkah apa yang dapat diambil dengan pembelajaran sejarah yang dimaksud?
\end{abstract}

Kata kunci : pembelajaran, sejarah, era disrupsi.

\section{Pendahuluan}

Fenomena perkembangan mutakhir di era disrupsi ini mengharuskan institusi pendidikan berbenah. Dunia pendidikan nasional, berusaha menyesuaikan. Pendidikan sebagai sarana penyalur ilmu pengetahuan (transfer knowledge) secara tidak langsung harus memiliki sistem yang dapat mendukung bagi terselenggaranya kegiatan tersebut. Era disrupsi ini memberikan kemudahan bagi kegiatan transfer pengetahuan dalam dunia pendidikan. Ketersediaan media pembelajaran yang canggih, sistem internet yang memadai, sistem pembelajaran dalam jaringan (online) dan berbagai kecanggihan dunia pembelajaran lainnya. Bagi peserta didik tentu bersiap untuk memiliki kecakapan dalam menggunakan perangkatperangkat pengetahuan sesuai kekinian.

Pendidikan sejarah merupakan salah satu sektor penting dalam memahami perkembangan peradaban di Negara Republik Indonesia. Pendidikan sejarah memberikan kontribusi dalam 
membangun moral bangsa. Perkembangan zaman yang sangat cepat seperti di era disrupsi saat ini, menuntut pendidikan sejarah dapat memberi penguatan perasaan nasionalisme.

Tujuan pembelajaran sejarah memiliki lima aspek pokok, yaitu 1) membangun kesadaran peserta didik tentang pentingnya waktu dan tempat yang merupakan sebuah proses dari masa lampau, masa kini, dan masa depan, 2) melatih daya kritis peserta didik untuk memahami fakta sejarah secara benar dengan didasarkan pada pendekatan ilmiah dan metodologi keilmuan, 3) menumbuhkan apresiasi dan penghargaan peserta didik terhadap peninggalan sejarah sebagai bukti peradaban bangsa Indonesia di masa lampau, 4) menumbuhkan pemahaman peserta didik terhadap proses terbentuknya bangsa Indonesia melalui sejarah yang panjang dan masih berproses hingga masa kini dan masa yang akan datang, dan 5) menumbuhkan kesadaran dalam diri peserta didik sebagai bagian dari bangsa Indonesia yang memiliki rasa bangga dan cinta tanah air yang dapat diimplementasikan dalam berbagai bidang kehidupan, baik nasional maupun internasional (Depdiknas, 2006)

Berpijak dari hal tersebut, maka beberapa penelitian dan kajian selama ini sebagian besar ternyata masih menunjukkan belum tercapainya secara optimal tujuan pembelajaran yang dimaksud. Berbagai fakta justru menunjukkan bahwa adanya kesan umum yang kurang positif dari para siswa tersebut terhadap proses pembelajaran sejarah di kelas. Para siswa sering mengungkapkan bahwa pengajaran sejarah di sekolah cenderung kurang menarik. Pelajaran sejarah di kelas juga sering dirasakan oleh siswa sebagai uraian fakta-fakta kering yang berupa urut-urutan tahun dan peristiwa saja. Pelajaran sejarah bahkan sering pula dirasakan oleh siswa sebagai pengulangan terhadap hal-hal yang sama (Widja: 1989).

Berdasarkan hasil salah satu survey dari sebuah koran ternama nasional juga menunjukkan bahwa keberadaan pelajaran sejarah bahkan telah dianggap kurang penting oleh siswa. Para responden siswa mengungkapkan bahwa pelajaran sejarah dianggap sebagai pembelajaran yang membosankan. Siswa menganggap bahwa isi materi-materi dalam pelajaran sejarah tidak variatif. Mereka juga menyatakan bahwa seandainya ingin belajar sejarah, maka lebih baik membaca koran atau sumber informasi lainnya. Sebab itu, mereka menganggap bahwa sejarah tidak harus selalu diajarkan di dalam sekolah (Deteksi Jawa Pos: 2004).

Diungkapkan pula oleh Hamid Hasan (1998) dalam penelitiannya terhadap pengajaran sejarah yang ternyata juga masih menunjukkan bahwa $71,4 \%$ pembelajaran sejarah hanya 
diarahkan untuk tercapainya pengetahuan tentang fakta-fakta sejarah, sedangkan hanya baru $6 \%$ saja yang diarahkan untuk pengembangan kemampuan berpikir.

Berpijak pada persoalan pembelajaran tersebut, pertanyaan yang muncul ialah 1). Bagaimanakah kondisi pembelajaran sejarah saat ini, 2). Permasalahan-permasalahan apa yang muncul dalam pembelajaran sejarah di sekolah saat ini ? 3). Gagasan apa yang yang dapat dijadikan alternatif dalam pengembangan pembelajaran sejarah saat ini hingga mampu menjadikan pembelajaran sejarah menjadi kajian menarik dan menantang bagi siswa ?

\section{Metode Penelitian}

Metode yang digunakan dalam penulisan ini adalah metode analisis, dalam kajian literatur yang bersifat analisis deskripsi melalui berbagai kajian kepustakaan dalam memperkuat analisis yang didukung dari berbagai sumber yang memiliki kedalaman teori dari para ahli tentang pendidikan sejarah. Melalui pendekatan analisis kajian keputusan dapat dijadikan dasar dalam mengembangkan perasaan nasionalisme dalam menghadapi perkembangan zaman yang terus berkembang khususnya dalam dunia pendidikan yang juga mampu mengubah pola pikir manusia dapat diwujudkan dalam karya- karya inovatif untuk menjawab kebutuhan masyarakat dalam era disrupsi.

\section{Hasil dan Pembahasan}

Kurang menariknya pembelajaran sejarah bagi siswa dewasa ini memiliki banyak faktor yang saling terkait. Berbagai faktor yang melingkupinya dapat ditinjau dari segi struktur kurikulum materi, sumber tenaga pendidik, model dan metode pengajaran yang digunakan, media pembelajaran, kurangnya sumber-sumber sejarah, serta faktor-faktor lain yang mempengaruhinya. Termasuk, kondisi motivasi dan minat siswa yang dari awal memang sudah tidak tertarik mempelajari sejarah. Berbagai permasalahan tersebut tentunya menuntut untuk segera dipecahkan oleh semua pihak, terutama bagi para praktisi pendidikan dan ujung tombak pembelajaran sejarah, yaitu para guru sejarah di sekolah.

Menurut I Gde Widja (1989), setidaknya terdapat empat kelemahan dalam pembelajaran sejarah, yaitu sebagai berikut. 
1. Pengajaran sejarah sangat didominasi oleh pengajaran hafalan dengan terlalu banyak menekankan "chalk and talk" di kelas dan sangat lemah dalam hal mendorong keterlibatan siswa dalam proses belajar.

2. Pengajaran sejarah di sekolah terlalu menekankan memorisasi dengan mengabaikan usaha pengembangan kemampuan intelektual yang lebih tinggi.

3. Pengajaran sejarah dianggap tidak relevan dengan kebutuhan serta minat siswa, karena siswa sulit untuk mengerti berbagai peristiwa sejarah yang terlalu memperhatikan tingkah laku orang dewasa yang ada di luar jangkauan pengalaman siswa.

4. Pengajaran sejarah kurang menekankan pengembangan konsep serta struktur peristiwa, karena terlalu banyak memberi tekanan pada peristiwa khusus tertentu sehingga konsep serta struktur yang lebih mencakup keseluruhan menjadi terabaikan

Berbagai ungkapan dan kritikan terhadap proses pengajaran sejarah di atas tentu merupakan masalah serius yang harus dipecahkan bersama. Hal ini mengingat bahwa pembelajaran sejarah pada dasarnya memiliki peran penting dalam mengaktualisasikan dua unsur pembelajaran dan pendidikan. Unsur pertama ialah pembelajaran dan pendidikan intelektual, serta unsur kedua ialah pembelajaran dan pendidikan moral bangsa (Isjoni: 2007). Pada unsur yang pertama tersebut, sejarah bukan hanya sebagai pemberian gambaran tentang masa lalu semata, namun juga sebagai upaya pemberian latihan bagi para siswa untuk berfikir kritis, menarik kesimpulan, mencari makna, serta menarik nilai-nilai dari peristiwa sejarah yang telah dipelajari. Melalui latihan berfikir kritis-analitis, para siswa diharapkan akan mampu dalam menghadapi tantangan jaman (Widja: 2002).

Sebab itu, maka perlu segera dikembangkan model rekonstruksi pembelajaran sejarah yang sejalan dengan karakteristik sejarah itu sendiri. Artinya, perlu dikembangkan pembelajaran sejarah yang terdiri dari unsur kritis, kronologis, perspektif waktu, prinsip kausalitas, serta pemahaman sejarah berdasarkan pendekatan multidimensional (Depdiknas: 2003). Salah satu gagasan yang dapat dijadikan alternatif untuk menaikkan posisi pembelajaran sejarah lebih menarik dan menantang bagi siswa dan guru ialah dengan pembelajaran yang berorientasi pemecahan masalha-masalah kekinian (kontemporer). Melalui pemecahan problem-problem kekinian, maka pembelajaran sejarah tidak hanya dianggap sebagai pelajaran masa lalu semata, namun dapat menjadi suatu kajian kritis terkait fenomena-fenomena masalah sosial kemasyarakatan masa kini. 


\section{Rekonstruksi Pembelajaran Sejarah Alur Mundur (Regresi)}

Pembelajaran sejarah dengan dasar "pemecahan masalah kekinian" dianggap tidak umum dilakukan disekolah. Pembelajaran sejarah dengan pola "pemecahan masalah kekinian" merupakan pembelajaran sejarah yang menjadikan materi-materi dan konsep sejarah sebagai bagian integral dalam mengatasi masalah-masalah sosial masyarakat kekinian dewasa ini, namun dengan berpandangan faktor historis. Pembelajaran model demikian dapat dikatakan sebagai alternatif menantang bagi siswa dan guru. Model pembelajaran sejarah yang dilaksanakan bahkan dapat dikatakan "regresi" dari proses pembelajaran sejarah yang umum. Jika pembelajaran sejarah yang umum dilaksanakan dimulai dari materi "masa lalu" menuju "masa kini", maka dalam pembelajaran sejarah melalui pemecahan masalah kekinian, maka proses mengajarkan secara "terbalik", yaitu mengajarkan materi-materi sejarah yang berangkat dari "masa kini " menuju "masa lalu".

Model pembelajaran sejarah dengan memulai masa kini dapat menjadikan pembelajaran sejarah lebih bermakna dan lebih bersifat aplikatif daripada pembelajaran sejarah yang telah umum. Model pembelajaran sejarah demikian bukan diawali dari pengajaran materi-materi atau konsep-konsep sejarah di buku-buku, namun pembelajaran sejarah model ini diawali dari permasalahan-permasalahan sosial konkret yang muncul di sekitar siswa untuk kemudian ditarik ke belakang terhadap latar belakang historis yang menyebabkan munculnya permasalahan tersebut. Atau dalam aspek ini posisi historis (materi sejarah) sebagai gambaran penjelasanpenjelasan suatu fenomena masalah-masalah sosial yang muncul pada amsa kini.

Langkah yang dapat digunakan aplikasi dalam pembelajaran sejarah pola regresi ini sebagai berikut.

1. Siswa diberikan suatu topik masalah-masalah sosial kekinian yang berhubungan atau masalah yang terkait dengan aspek-aspek kesejarahan.

2. Siswa lalu dapat diminta secara berkelompok untuk mengidentifikasi permasalahan tersebut, seperti faktor-faktor apa yang megakibatkan munculnya suatu permasalahan.

3. Siswa diminta untuk mengkaji/menganalisis, serta memecahkan permasalahan yang muncul di dalam topik dengan berpedoman pada aspek-aspek historis.

4. Siswa diharuskan mengungkapkan gagasan, argumen serta kesimpulan berdasarkan sumber-sumber sejarah atau literatur terkait

5. Siswa menjelaskan solusi dari pemecahan masalah dari munculnya problem. 
Melalui topik masalah kekinian tersebut, maka siswa diajak untuk berefleksi diri terkait topik masalah sosial tersebut dengan menarik pemahaman siswa menuju masa lampau di Abad $18 \mathrm{M}$, yaitu ketika wilayah Indonesia masih di bawah kolonialisme Belanda.

Siswa diminta membuat perbandingan terkait kondisi perkembangan industri gula saat ini (tahun 2013) dengan perkembangan industri gula di jaman kolonial (abad 18 M). Siswa dapat diberikan pemahaman objektif melalui pertanyaan-pertanyaan yang menantang. Beberapa pertanyaan pilihan menantang seperti berikut ini.

1. Pada masa kolonial (penjajahan belanda) di abad $18 \mathrm{M}$, wilayah nusantara (Jawa) mampu menjadi produsen dan pengekspor gula terbesar di dunia, namun demikian mengapa saat ini negara kita (Indonesia) justru melakukan hal sebaliknya, yaitu mengimpor gula dari luar negeri ?

2. Permasalahan atau kendala apa yang kalian temukan sehingga pemerintah Indonesia sekarang justru mengimpor gula dari luar negeri ?

3. Merujuk kondisi masa lalu, bagaimanakah strategi pemerintah kolonial Belanda pada masa itu sehingga mereka mampu menjadikan wilayah nusantara (Jawa) sebagai penghasil gula tersbesar di dunia?

4. Apa upaya-upaya yang dapat kalian lakukan atau sumbangan apa yang dapat kalian berikan bagi pemerintah dan masyarakat untuk membangkitkan industri gula di tanah air saat ini agar mampu berjaya kembali seperti di abad $18 \mathrm{M}$ ?

Melalui stimulus pertanyaan-pertanyaan tersebut, siswa dapat dibimbing menuju latar belakang aspek historis guna memecahkan masalah-masalah sosial kekinian. Melalui pembelajaran sejarah yang "terbalik" demikian, maka posisi materi-materi yang terdapat dalam pelajaran sejarah bukan hanya sebagai aspek pengetahuan belaka. Materi-materi yang terdapat di dalam pelajaran sejarah dapat menjadi "selangkah lebih maju" sebagai pandangan gambaran solusi pemecahan masalah-masalah kekinian. Melalui proses pembelajaran sejarah yang demikian, maka diharapkan akan menarik minat, motivasi, dan aktifitas siswa untuk belajar sejarah. Sejarah tidak akan lagi dianggap sebagai pelajaran masa lalu semata, namun lebih dari itu, sejarah akan dianggap sebagai pelajaran yang mampu memecahkan permasalahanpermasalahan sosial kemasyarakatan pada masa kini.

\section{Simpulan}

668 | Seminar Nasional Sejarah ke 4 Jurusan Pendidikan Sejarah Universitas Negeri Padang 
Berbagai permasalahan dan kendala yang muncul dalam pembelajaran sejarah dewasa ini perlu direkonstruksi agar kesan bahwa pembelajaran sejarah membosankan tidak akan ada lagi. Salah satu alternatif yang dapat dilakukan yaitu dengan "memutar balik" pola pembelajaran sejarah saat ini di sekolah. Jika pada umumnya pelaksanaan pembelajaran sejarah berangkat dari materi masa lalu menuju masa kini, maka perlu dilaksanakan pembelajaran dengan berangkat dari masa kini menuju masa lalu. Salah satu strategi yang dapat dilaukan ialah melalui pembelajaran sejarah dengan pemecahan masalahan masa kini. Artinya, materi-materi yang terdapat dalam sejarah bukan hanya digunakan sebagai fakta pengetahuan belaka, namun lebih dari itu bahwa materi-materi yang terdapat pada pelajaran sejarah digunakan sebagai pemahaman solusi pemecahan masalah di masa kini.

\section{DAFTAR PUSTAKA}

BSNP. 2006. Panduan Penyusunan Kurikulum Tingkat Satuan Pendidikan Jenjang Pendidikan Dasar dan Menengah. Jakarta: Depdiknas.

Depdiknas. 2003. Kurikulum 2004 SMA: Pedoman Khusus Pengembangan Silabus dan Penilaian Mata Pelajaran Sejarah. Jakarta: Dikti Dirjen PDM-DPMU.

Hasan, Hamid. 1998. Kebijakan dan Pelaksanaan Sejarah di Lingkungan Departemen Pendidikan dan Kebudayaan dalam Simposium Pengajarn Sejarah. Jakarta: Depdiknas. Isjoni. 2007. Pembelajaran Sejarah Pada Tingkat Satuan Pendidikan. Bandung: Alfabeta. Jawa Pos. Deteksi. 2004. "Sejarah Penting Nggak sih ?". 20 Desember 2004. Surabaya. Sanjaya, Wina. 2006. Pembelajaran dalam Implementasi Kurikulum Berbasis Kompetensi. Jakarta: Kencana.

Widja, I Gde. 1989. Sejarah Lokal Suatu Perspektif dalam Pengajaran Sejarah. Jakarta: Depdikbud Dikti PPLPTK.

-------. 2002. Menuju Wajah Baru Pendidikan Sejarah. Yogyakarta: Lappera Pustaka Utama. 